http://jmscr.igmpublication.org/home/ ISSN (e)-2347-176x ISSN (p) 2455-0450

crossref DOI: https://dx.doi.org/10.18535/jmscr/v9i1.26

\author{
Journal Of Medical Science And Clinical Research \\ IGM Publication \\ An official Publication of IGM Publication
}

\title{
A Rare Presentation of Right Iliac Fossa Mass- Perforated Ileal Gastrointestinal Stromal Tumour
}

\author{
Authors \\ Dr K. Nithya ${ }^{1^{*}}$, Dr R. Ramesh ${ }^{2}$ \\ ${ }^{1}$ Post Graduate, Department of General Surgery, Rajah Muthiah Medical College, Chidambaram \\ ${ }^{2}$ Professor, Department of General Surgery, Rajah Muthiah Medical College, Chidambaram \\ *Corresponding Author \\ Dr K. Nithya
}

No.115, WHP Hostel, Annamalai Nagar, Annamalai University, Chidambaram-608002, India

Abstract
Gastrointestinal stromal tumors are tumours of the gut mainly seen in small bowel 25\%, stomach 50 -
$60 \%$.It is 0.2-0.3\% of all the GI tumours. It's a rare but most common non epithelial small bowel tumor.
It usually attains large size presenting as a palpable mass. They have lesser affinity for lymphatics. In
this study it presented as an acute abdomen with right iliac fossa mass. Contrast enhanced computed
tomography of abdomen revealed an enhanced peripheral lesion with features of peritonitis, suspicion of
caecal perforation. Laprotomy findings showed gangrenous ileal gastrointestinal tumour over
antimesentric border of ileum pathological study revealed a spindle type tumor. In my study this case
was a rare and unusual differential diagnosis of right iliac fossa mass. This needs expertise suspicion
and timely intervention to manage masquerading acute abdomen, to prevent morbidity, mortality.
Keywords: Terminal ileum, caecum, intestinal perforation, hematochezia.

\section{Case Report}

A 63 year old female presented with abdominal pain for 3 days, dull aching, not radiating, more on the right lower abdomen, history of nausea, vomiting, two episodes of haematochezia present from the previous day night. On clinical examination patient had pallor, tachycardia, hypotension, abdomen showed tenderness more on right iliac fossa with guarding, rebound tenderness. Mass of size $5 \times 6 \times 2 \mathrm{~cm}$ made out per rectal examination revealed normal tone, no growth, blood stained fingers. Chest and abdominal $\mathrm{X}$ ray normal USG abdomen showed ill-defined mass with minimal free fluid with probe tenderness. Cectabdomen showed enhancing encapsulated peripheral lesion in base of caecum and peritonitis probably a sealed caecal perforation.

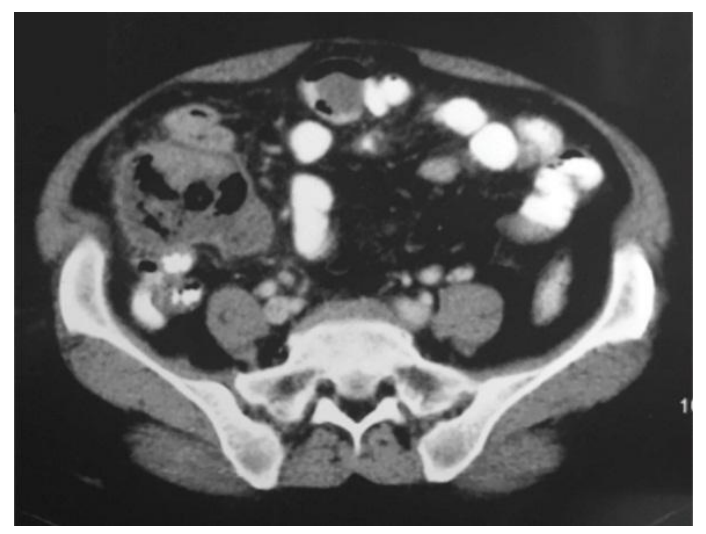

Figure 1: CT Findings 
Operative Findings: Exoloratory laprotomy was done which revealed adherent small bowel and omentum over a part of caecum, abdominal wall. On meticulous dissection structures revealed were gangrenous, perforated small bowel tumour of size $6 \times 7 \times 3 \mathrm{~cm}$, in the antimesentric border of ileum of about $90 \mathrm{~cm}$ proximal to ileocaecal junction. Rest of the abdomen findings normal. Segmental resection of ileum with part of mesentry, primary anastamosis was done. Peritoneal lavage with enormous amount of normal saline was done.

Abdomen closed in layers.
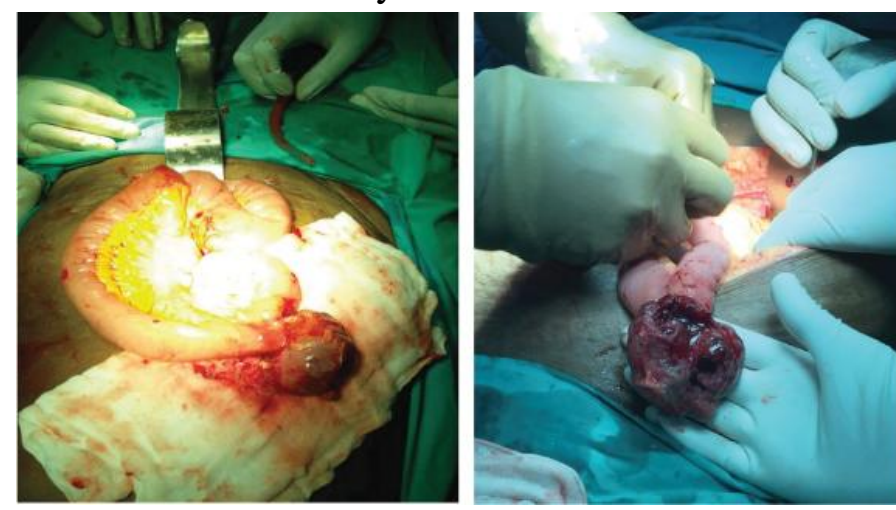

Figure 2: INTRA- OP findings

Pathological Findings: Findings revealed submucosal mass of size $6 \times 7 \times 3 \mathrm{~cm}$ extending to antimesentric border of ileum. Microscopy revealed a low grade, intermediate risk $\mathrm{pT} 3 \mathrm{pNx}$ tumour of spindle cell type. Immunohistochemistry positive for CD 117 , confirmed the diagnosis.

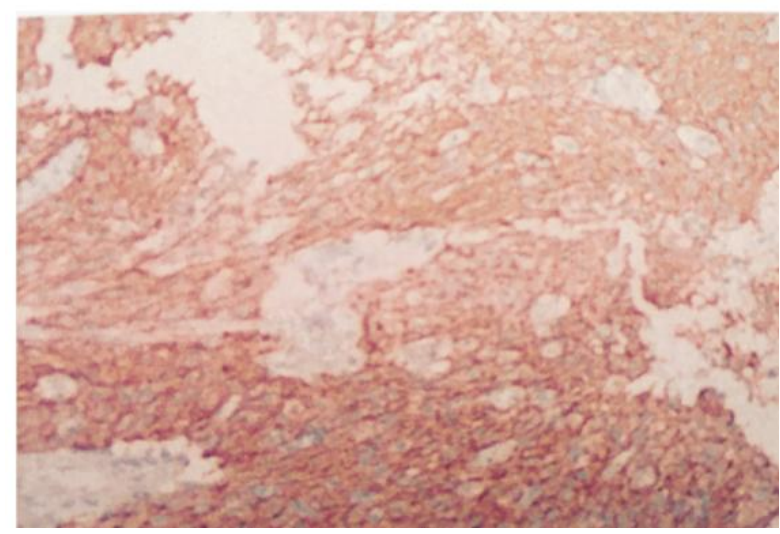

Figure 3: Histological findings

Post-operative period was uneventful patient discharged on 10th day. Imatinib therapy started and follow up advice given.

\section{Discussion}

Gastrointestinal tumors are non-epithelial tumors of mesenchymal origin, they arise from interstial cells of cajal, equal in both sexes. More common in 5th to 6th decade of life. They are mostly indolent diagnosed incidentally. Usually smaller ones are silent, huge tumourspresent with unrelated symptoms, mostly metastasize at the time of presentation. Major complications are GI bleeding, intestinal obstruction, rarely perforation. These tumours may be a part of Meckels diverticulum reported in seven cases. ${ }^{4}$ Major complication is bleeding ${ }^{2}$ rarely perforation. ${ }^{6}$ In five cases. as a case of abdominal cocoon in two cases. ${ }^{5}$ Only two cases reported presenting as right iliac fossa mass in jejunal gist and other is caecal gist, as a diffuse swelling in right iliac fossa and right lumbar regions. ${ }^{8}$ In our case terminal ileal gist presented as right iliac fossa mass with lower Gi bleed.

The pathological diagnosis and immunohistochemistry staining is required to confirm diagnosis.

\section{Immunohistochemical markers in GIST}

\begin{tabular}{|l|c|}
\hline Marker & Positivity (\%) \\
\hline CD117 & $94-98$ \\
\hline CD 34 & $60-80$ \\
\hline SMA & $20-30$ \\
\hline S100 & 10 \\
\hline DESMIN & $<5$ \\
\hline
\end{tabular}

Recently identified DOG 1 Antibody was positive in $85-95 \%$ of CD 117 + GISTS, in $30-36 \%$ of CD117 -VE GISTS. This antibody tests is useful in tumours not identifiable on C- kit immunohistochemistry. ${ }^{11}$

As per Fletcher cd et al, proposed classification system, mitotic count is main prognostic factor.

\section{Classification system by Fletchet et al}

\begin{tabular}{|l|c|c|}
\hline $\begin{array}{l}\text { Risk of } \\
\text { Malignancy }\end{array}$ & $\begin{array}{c}\text { Size of } \\
\text { tumour }\end{array}$ & $\begin{array}{c}\text { Mitotic counts } \\
\mathbf{( 5 0} \text { HPF })\end{array}$ \\
\hline Very Low & $<2$ & $<5 / 50$ \\
\hline \multirow{2}{*}{ Intermediate } & $<5$ & $6-10$ \\
\cline { 2 - 3 } & $5-10$ & $<5$ \\
\hline \multirow{3}{*}{ High } & $>5$ & $>5$ \\
\cline { 2 - 3 } & $>10$ & Any counts \\
\cline { 2 - 3 } & Any size & $>10$ \\
\hline
\end{tabular}


Ro surgical resection is the standard treatment. As lymph node metastasis is rare, lymph node dissection is least performed. survival rate for 5yrs after perforation is $20 \%$, while for advanced tumours is $45 \%$,reason is due to peritoneal dissemination. In advanced cases imatinib improved overall survival rates. Adjuvant therapy should be given for four years followed by primary resection and perforation. ${ }^{15}$

\section{Conclusion}

This patient with right iliac fossa mass as acute abdomen was incidentally diagnosed to be a perforated gist arising from the ileum. So apart from other causes, a perforated gist must also be considered. High suspicion and timely surgical intervention needed to reduce morbidity and mortality.

Financial or Other Competing Interests: None

\section{References}

1. Connolly EM, Gaffney E, Reynolds JV. Gastrointestinal stromal tumours. $\mathrm{Br} \mathrm{J}$ Surg. 2003;90: 1178-86.(pub med)

2. Miyata S, Bliss DW. A gastrointestinal stromal tumour found in perforated Meckels diverticulum. Surg case reports. Springet.2016; 2(1): 67 (pmc free article)

3. Dematteo RP, Lewis JJ, Leung, Mudan SS, Woodruff JM, Brennan MF. Two hundred gastrointestinal stromal tumours: recurrence patterns and prognostic factors for survival. Ann Surg. 2000;231(1):(5158 pmc free article)

4. Lopez-Tomassetti Fernandez EM, Hernandez JR,Usha M.Perforated gastrointestinal stromal tumour in Meckels diverticulum treated laprascopically. Asian J Endos surg. 2013;126-129.(pub med)

5. Kumar V, Rau, Kamnaths. Perforated Gist in jejunum- A rare cause of abdominal cocoon $\mathrm{J}$ clin Diagn Res. 2014;8:132- 133.(pmc free article) (pubmed)
6. Skipworth J, Fanshawe A, West M, Al Bahrani A. Perforation as a rare presentation of gastric gasstrointestinal stromal tumours: a cade report and review of the literature. Ann R Coll Surg Engl 2014;96 (1):01-05 (pmc free article) (pub med)

7. Nancharaiah $\mathrm{P}$, Venkateswaralu $\mathrm{MC}$, Aishwarya M. Gist in Rif masquerading as appendicular mass. IOSR J DENT med sci 2016,15:2279-2861.

8. Sreevastha MR caecal gastrointestinal stromal tumours .curr opi gastro enterol. 2012; 28 113-23.(pub med)

9. Grover S Adhley SWZ, Raut CP. Small intestine gadtrointestinal stromal tumours. Curropingastroenterol 2012, 28:11323(pubmed)

10. Judson I.Gastrointestinal syromal tumors, biology and treatment Ann Oncol.2002, 13 (suppl) 287- 89. (pubmed)

11. Bucher P,Taylor S, Villiger P, Morel P, Brundler M A. Are there any prognostic factors for small intestinal tumours? Am J surg. 2004, 187:761-66. (pubmed)

12. Liegel B, Hornick JL, Corless CL, Fletchet CD. Monoclonal antibody DOG1.1 shows higher sensitivity than kit in the diagnosis. (pub med)

13. Crosby JA, Catton CN,Davis malignant gastrointestinal stromal tumours of the small intestine:(pub mef)

14. Fletcher CD, Berman JJ, Corekess C. Asian consensus guidelines for the diagnosis and management of gist. 2002, 33 (5)459 - 465.(pubmed)

15. Koo DH, RyuMH, Kim Km, yang Hk, Sawaki A, Hirota S, et al.A consensus approach

hum.pathol.canc.res.treat.2016,48:4,115566. (pmc free article). 